\title{
THE DEVELOPMENT OF RURAL PERIPHERAL AREAS IN LITHUANIA: THE CHALLENGES OF SOCIO-SPATIAL TRANSITION
}

\author{
Gintarè Pociūtè-Sereikienė, Edis Kriaučiūnas ${ }^{1}$
}

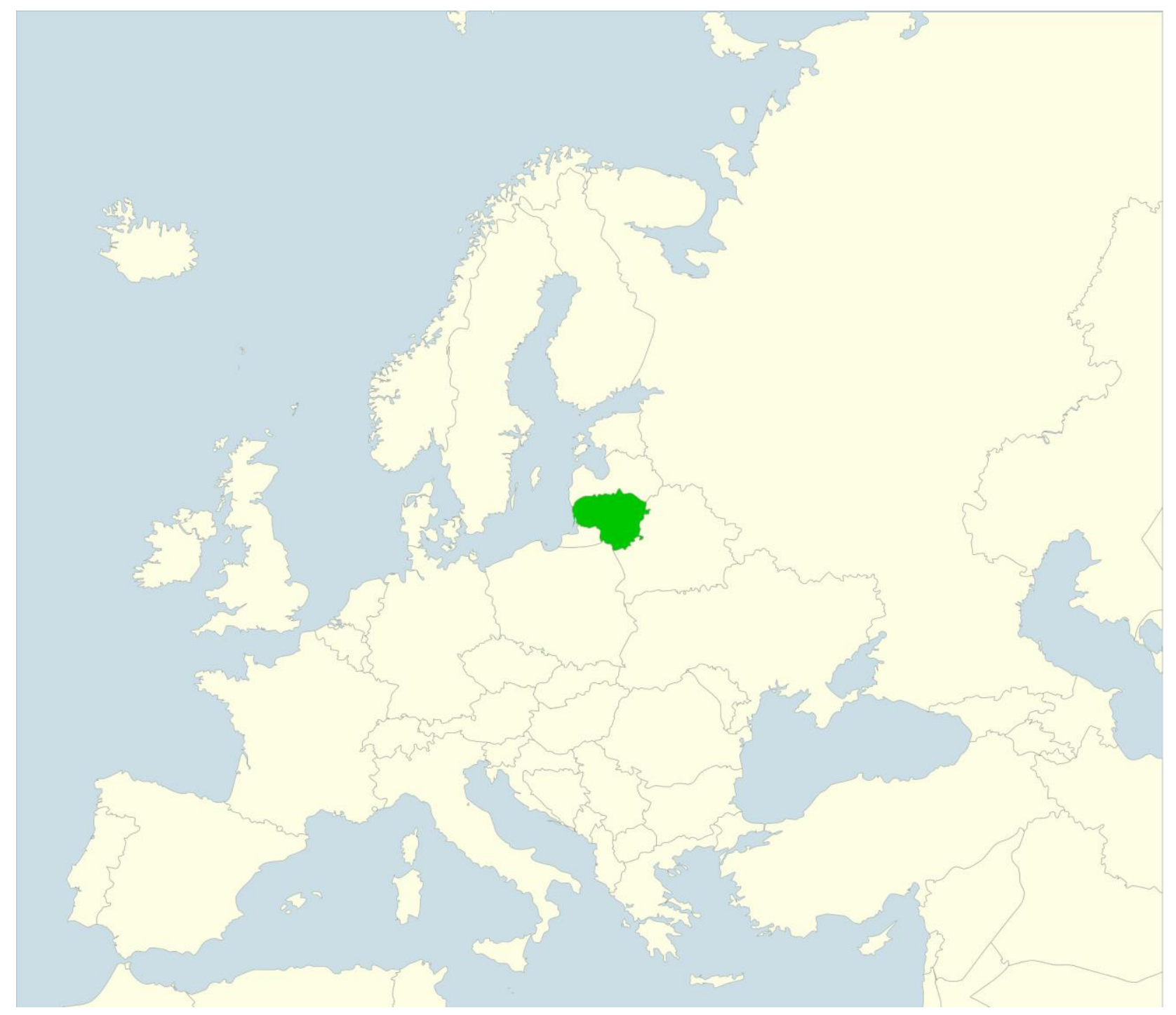

1 Dr. Gintarè Pociūtè-Sereikienè, gintarei.pociutei@gmail.com Dr. Edis Kriaučiūnas, edis.geo@gmail.com Lithuanian Social Research Centre, Institute of Human Geography and Demography,A. Goštauto st. 9, LT-01108, Lithuania 
Abstract: The collapse of the Soviet utopian world, where the government sought to plan and control economic and social processes, caused a wave of significant changes in the post-socialist countries. The territorial regrouping of citizens is one of the hard to control changes that started at the end of the 1990s in Lithuania. This article identifies the major changes in the settlement system in Lithuania and its effects on peripheral areas. The main scope of this article is an analysis of the potential of residents from peripheral areas to adapt to the rapidly changing socio-economic environment. For the analysis, we used data and information gathered during field trips to peripheral rural areas throughout the country between 2013 and 2014. This study found that the residents who remained in peripheral areas had several opportunities in rapidly changing environment after Lithuania gained its Independence in 1990. Interviews with local authorities allowed us to define three groups of residents and their potential to adapt to the labour market: those who are active, those who are passive and those who choose social benefits instead of a work salary. The survey results allowed us to predict that the 'central-peripheral' spatial structure will be one of the main factors influencing regional development in Lithuania in the near future.

Keywords: peripheral areas, rural settlements, socio-spatial transition, territorial regrouping, adaptation, migration, Lithuania

Santrauka: Komunistinio režimo žlugimas sukèlè post-socialistinèse valstybèse pokyčių bangą. Vienas iš sunkiausiai valdomų procesų Lietuvoje - gyventojų teritorinis persigrupavimas, vykstantis besiformuojant naujoms ūkio ir gyvenviečių erdvinèms struktūroms. Straipsnis parašytas siekiant išsiaiškinti specifines periferizacijos proceso ypatybes Lietuvoje. Ypatingas dèmesys skiriamas paprastų periferijos gyventojų gebèjimo prisitaikyti prie sparčiai kintančios aplinkos analizei. Analizuojant daugiausia naudoti duomenys, surinkti 2013-2015 m. ekspediciju po kaimiškas periferines vietoves metu. Tyrimas leidžia teigti, kad periferijoje liekančių gyventojų adaptacija skirstytina i aktyvią ir pasyvią. Kita adaptacijos grupé - gyventojai, nesugebèję prisitaikyti prie pokyčių. Tyrimo rezultatai leidžia prognozuoti, kad "centro-periferijos" veiksnys artimiausiu periodu bus vienas svarbiausių veiksnių lemiančių konkrečios teritorijos raidą.

Raktažodžiai: periferinès teritorijos, kaimo gyvenvietès, socio-erdviniai pokyčiai, teritorinis persigrupavimas, prisitaikymas, migracija, Lietuva

\section{Introduction}

At the end of the last century, all the countries that were part of the former Soviet Union and Warsaw block broke free from the closed-off Communist world. The collapse of Soviet Union caused a wave of significant changes in the post-socialist countries. In this article, we would like to point out that the changes that arose during the transition from a planned to a market-led economy period were very unfavourable for the development of peripheral areas in Lithuania.

The majority of the Lithuanian population thought that after the restoration of Independence, their quality of life would improve rapidly. Nobody thought about possible negative changes. It was believed that 'open freedom' would solve everything itself. Some things were solved, although other issues that needed to be solved were only highlighted. The settlement network was one of these addressed issues. Hardly anyone thought that the changed conditions would lead to the resettlement of society. The Soviet government was deservedly much-maligned, but it had developed a settlement network system that more or less matched its economic development 
model. In other words, people lived nearby their places of work. There were ten regional centres that had been developed in Lithuania, and the government had attempted to spread people around the country more or less evenly (Maldžiūnas, 1970; Šešelgis, 1975, 1996; Vanagas et al., 2002; Vaitekūnas, 1989). To fulfill the conception of 'Unified settlement system' was not an easy task, and it did not always succeed. In some places, the depopulation was intensive and was similar to (or even exceeded) current tendencies.

During the 27 years of Independence, living and work conditions have changed fundamentally. According to the 2011 data, no more than half of rural residents were living and working in the same place in Lithuania (Pociūtè-Sereikienè et al., 2014). The huge differences in regional development have revealed that the major cities and their suburbs are spreading, whereas peripheral rural areas are undergoing a great demographic decline (Ubarevičienè and van Ham, 2017). A great number of young people in peripheral rural areas do not see any opportunities, so they are tending to leave; rural society is ageing, the schools are closing, a significant number of people live on social benefits, and long-term unemployment is causing specific problems such as alcoholism, which in turn increases the number of families at social risk, and so on (Daugirdas et al., 2013; Kriaučiūnas et al., 2014).

It is noticeable that the changes are not satisfactory for people from peripheral areas when looking at election results in almost all Eastern Europe (and not only there). The fact that unexpected election results are determined by a confrontation between the city and the countryside has already been publicly acknowledged (Lyman, 2016).

We chose Lithuania - a relatively small country in Central and Eastern Europe - as a case study area. It might seem that in a country of only around 65.3 thousand square kilometres, the peripheralisation process should not be significant, but it is. The fact that social inequality in Lithuania is still increasing was even emphasised in the latest report from the European Commission (2017). Also, recent studies (Burneika, 2012; Mačiulytė and Bagočiūtè, 2008; Pociūtè, 2014; Ubarevičienè and van Ham, 2017) revealed that Lithuania is highly polarised with significant regional disparities within the country.

This article identifies the major changes in the settlement system in Lithuania and their effects on peripheral areas. The changes in the settlement system are fundamentally linked to the development of the socioeconomic situation in the country. This article is dedicated to analysing the critical and controversial above-mentioned processes that are resulting in the rapid peripheralisation of rural areas. The article analyse the potential of residents from peripheral regions to adapt to the rapidly changing socio-economic environment. The social adaptation of these residents is already a crucial issue in Lithuania (LR Vyriausybès Nutarimas 2003, 2007). In the future, this issue is likely to become more important due to increasing regional polarisation. With this article, we try to answer the questions, 'what is happening in rural peripheral areas that are losing their inhabitants?' and 'what is happening with the people who stay there?'

Our survey results allow us to predict that the 'central-peripheral' spatial structure will be one of the main factors influencing regional development in Lithuania in the near future. In this article, we state that there is a great need to increase the focus of local communities (Chevalier et al., 2017; Juska et al., 2005) and government institutions on the challenges that peripheral regions face.

\section{Research background}

\section{Understanding peripherality}

There are a number of different perceptions of what a periphery is, which often depend on the discourse that is used to define this phenomenon (Kühn, 2015).

The notion of a periphery in the academic literature often varies depending on the locational, demographic, socioeconomic or other indicators used (Burbulytè-Tsiskarishvili, 2012; Copus, 2001; Gutiérrez and Urbano, 1996; Janc, 2006; Jerabek, 2006; Keeble, 1989; Kinsey, 2006; Marada et 
al., 2006; Nagy, 2006; Rokkan and Urwin, 1982; Spiekermanm and Wegener, 1996; Vaishar, 2006). The concept of a periphery based on physical distance that prevailed in Europe for a long time is losing its importance; now when determining peripheries, the accessibility of human, social and economic potential is being emphasised as well, indicated with the term 'aspatial peripherality' (Copus, 2001).

Bearing in mind both the spatial and 'aspatial' dimensions, we can summarise the statements by Blowers and Leroy (1994) and Elcock (2014), who state that to live in a periphery means to live in an area that is 'geographically remote, economically marginal, politically powerless and socially inhomogeneous' (Blowers and Leroy, 1994: 203); or, as Elcock (2014) stresses, in a region that is 'distant, different and dependent' ( $p$. 323) where 'its needs and requirements have tended to be neglected by highly centralised Government' (p. 330). This means that what makes a periphery a periphery is a difference, powerlessness, distance and dependence on one or several centres.

The essence of the conception of a periphery has to be explained in accordance with the binary logic conception of a core-periphery system: there would be no periphery without a centre, although at the same time, the periphery remains in the shadow of the centre (Daugirdas and Burneika, 2008; Deleuze, 2004; Marada et al., 2006; Vaishar, 2006). This concept adds clarity to polarisation: the growth of the centre determines the peripheralisation of other territories not only by attracting people, but also by absorbing economic potential, infrastructure and governmental functions (Blowers and Leroy, 1994; Eriksson, 2008; Lang, 2012; Spoor, 2013). The result of centralperipheral relations is the retardation of the periphery. Periphery is seen as the place of constant conservatism and passivity, an unattractive place to live and an occupation with business (Daugirdas and Burneika, 2008; Krugman, 2010; Raagmaa, 2003, Swain, 2016). The representatives of peripheral regions have a weaker vote in the solution acceptance process, the representatives of centres dwarf those of peripheries by not acknowledging their opinions or claiming that it is not topical. The appearance of peripheries is said to be the consequence of peripheralisation (Kühn and Bernt, 2013; Lang, 2015). However, peripheralisation is perceived as being an increase in socio-spatial inequalities, the 'production' of peripheries (Kühn, 2015: 369); or as Bürk (2013: 168) defines: 'socio-spatial processes of demographic change (out-migration), the lack and decline of infrastructures (disconnection) and the growing constrains on achieving multi-level support of local development (dependence)'.

Usually, we look at a periphery from a city perspective as we try to understand what is happening in the rural peripheral area. The negative aspects of peripheral areas are over-estimated in public and in the literature; therefore, peripheral areas are usually equated with negative phenomena (Miggelbrink and Meyer, 2015). How these areas are seen by 'others' is very important (Bürk, 2013; Eriksson, 2008; Lang, 2012; Willett, 2010). When looking from a central position, peripheries are described using epithets such as regions of 'rural idyll', 'lagging behind', 'a slow place of life', 'being the past', etc. (Willett, 2010; Miggelbrink and Meyer, 2015). Self-images and 'stigmatisation' contribute to peripheralisation processes (Bürk, 2013; Lang, 2012). These regions become unfavourable places to live in; therefore, the younger generations in particular try to 'escape' from peripheral areas (Miggelbrink and Meyer, 2015).

In our case, in Lithuania, peripheral rural areas fall within the conception framework, thus meeting the listed descriptions: different, distant, powerlessness, dependent, stigmatised. Therefore, in this article, we understand the periphery in a broad sense, defining it as rural areas left on the edge of globalisation. These are areas that cannot keep up with a fast-moving world, so the people from them have to find opportunities that would allow them to live well, or to leave and find a better place to live.

However, we have to mention the other functions of the periphery that highlights the positive side: peripheries are attractive regarding their naturalness, quietness; the periphery serves as the place for rural tourism. 


\section{Methodological remarks}

This article does not intend to analyse in detail the specific socioeconomic processes appearing in peripheral areas in Lithuania (as mentioned in the Introduction, works on this topic have already been written by the authors of this article). In this article, we aim to raise and discuss topical questions linked to the potential of residents of peripheral regions in Lithuania to adapt to the rapidly changing social environment and economic conditions. The residents' potential to adapt to the socioeconomic environment in this article is understood as their potential to adapt to the labour market. The main feature of this adaptation is the fact that after the collapse of Soviet economic structure, the majority of residents lost their jobs and when the new neoliberal economic system had been developed, there were less created workplaces in peripheral territories than the number of working age people that were living in these settlements. The residents of the periphery ought to change not only the workplace but in most cases even the place of residence. Therefore, in the post-socialist space (specifically in Lithuania), the adaptation to the labour market has the territorial migration component as well. This is because work migration determines the emigration of people from peripheral regions to major cities or abroad, together influencing the changes in the social structure (Pocius, 2007).

The research presented in this article integrates both quantitative and qualitative analysis methods: an analysis of the scientific literature, an analysis of statistical data (Statistics Lithuania, 2017), deductive and inductive methods, observations during field trips and semi-structured interviews with local authorities in wards (LAU-2 regions, It. seniünija). In 2013-2014, we visited 55 selected settlements $^{2}$ (in different wards all over Lithuania and interviewed people representing these settlements: chairs of wards (if the settlement was in the centre of the ward), chairs of local communities (if the settlement did not have the status of centre of the ward) or other people representing the settlements' communities. The purpose of this research was to find out any functional changes that appeared in rural settlements during the 25-year period of Independence. During the research, we collected data on changes in the residents' service institution network, we looked for links between the inhabitants' residential and work places and we analysed the main socioeconomic problems. The information we collected allowed us to make a more general picture of current tendencies in rural settlements, and to understand the development of the settlements the rise or fall of the analysed residential territories and any possible further development tendencies.

\section{The peculiarities of the reconstruction of the settlement system during the Soviet period}

For fifty years (1940-1990), Lithuania was a legal part of the Soviet Union, where the principles of central planning were consistently enforced. Therefore, in order to understand the current processes of increasing polarisation in Lithuania, it is necessary to present in brief the economic and spatial development policy of the territory that was implemented during the Soviet period. This Soviet policy had two main objectives: The first was political - to create a 'perfect' communist society where every person had to serve a common goal that was determined by the government and to follow the Party's rules. The second objective was more specific and economic. This communist country had to modernise its economy in order not to lag behind the 'Western world' and due to its need to provide its citizens (who were rapidly increasing in number) with basic food and consumer goods (Vanagas et al., 2002).

\footnotetext{
2 These settlements were selected with the purpose of demonstrating the diversity of rural settlements. They were also selected in accordance with their geographical location, size, and functional peculiarities. We only investigated settlements that had or could potentially have any institutional features (as the majority of small settlements (with fewer than 100 inhabitants) did not have any institutions). The smallest settlement included in this research - Varkale (Kaišiadoriai dis., Nemaitoniai ward centre) had 68 residents (according to the 2011 Census data). In total, this research included ten settlements with fewer than 200 residents; 29 settlements with 200-500 residents; 13 settlements with 5001.000 residents; and three settlements with more than 1,000 residents.
} 
It is worth mentioning, that the change of settlement system was not limited to migration control (it was rather hard to control migration in Lithuania). In Lithuania, it was tried to readjust the settlement system to Soviet economic system and to integrate it to the mentioned political task - to create the Communist society.

The resettlement of rural territories was directly connected to the general development of the settlement system in Lithuania, which was based on the 'Unified settlement planning system' conception, a popular regional planning scheme in the Soviet Union (Maldžiūnas, 1970; Šešelgis, 1975, 1996; Vanagas et al., 2002). The main feature of the unified settlement system was the idea that the countryside's economy and the development of the settlement system should be strictly controlled $^{3}$; the residents should be spread all over the country and there should be strong regional centres (with a surrounding network of towns and villages) that would reduce the dominance of the largest cities (especially the capital Vilnius) (Šešelgis, 1975, 1996; Vanagas et al., 2002; Vaitekūnas, 1989).

In the Soviet Union, the resettlement of citizens was strictly regulated through controlling the registrations of living places (more about rural society in Soviet settlements might be read in Juska et al., 2005: 6-7). The settlement system was enforced using directive methods. However, despite the fact that the government sought to regulate the development of the settlements, in reality it did not always manage to control it. Occasionally, unplanned settlements appeared and planned ones declined, especially in peripheral areas. It should be stressed that the consolidation of rural settlements during the Soviet period was processed in the context of a general increase in the population, although the number of rural residents was decreasing. Depopulation in some peripheral rural areas had reached two per cent per year (Maldžiūnas, 1970). The total number of residents in Lithuania increased from 2.69 million to 3.69 million (37 per cent) during the period 1959-1989, whereas the rural population decreased from 1.67 million to 1.18 million (-29 per cent) (Census, 1991). All types of settlements: cities, towns and villages, grew at the expense of smaller villages and homesteads.

The Soviet 'reform' of rural territories was socially painful and forced (especially during 1960-1970) in Lithuania, which was essentially an agrarian country until World War II. Later, remote rural areas became less and less attractive, so the residents, and especially young people, left rural settlements and moved to cities. At the end of the Soviet period, there were initiatives to block this emigration process, but they were unsuccessful (Vaitekūnas, 1989). The residents of peripheral rural regions approximately equally migrated to major cities, or to towns in the same administrative district, or to other villages (Rupas and Vaitekūnas, 1980).

\section{General tendencies of demographic and spatial changes after Lithuania regained its Independence}

With the collapse of the Soviet Union, the unified settlement planning system also started to crumble, in this way becoming the main starting point for the deepening gap between the centre and the peripheries, and in particular giving rise to the demographic, social and economic decline, as well as the cause of regions lagging behind (Figure 1) (Burneika, 2012; Juska et al., 2005; Mačiulytė and Bagočiūtè, 2008; Pociūtè, 2014). The transition from a planned to a market economy caused a lot of companies to become non-competitive and unable to survive in the new market system (Burneika, 2006). This in turn had an impact on the decline and intensive peripheralisation of some artificially viable regions, as well as some regionally important industrial cities that were

\footnotetext{
${ }^{3}$ According to the conception of the 'Unified settlement system' there were plans to develop ten regional industrial centres (with a distance between them of 100-120 km), around 50 administrative district centres and around 250 microregional centres (the majority historical towns). The smallest link in the country's hierarchical settlement system was the rural collective farm settlement system (kolkhoz and sovhoz), which consisted of a central kolkhoz settlement, 1 or 2 sovhoz subsidiary settlements and other small villages that were to be destroyed (Šešelgis, 1975; Maldžiūnas, 1970; Vaitekūnas, 1989).
} 
built during Soviet times and that are currently coping with a socioeconomic and demographic crisis (Mačiulytè and Bagočiūtè, 2008).

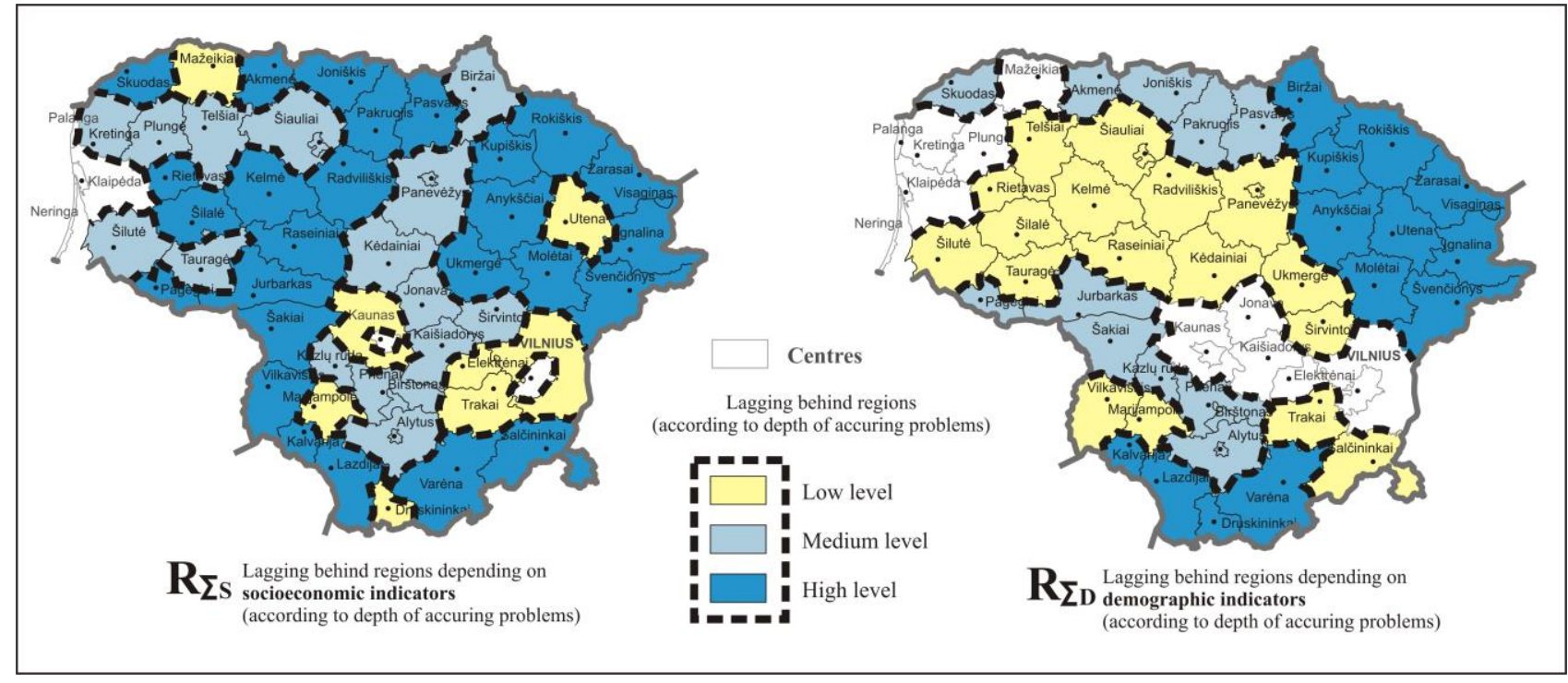

Fig 1. Lagging regions in Lithuania. Source: Pociūtè, 2014

In general, during the last 25 years, Lithuania has lost 23 per cent of its inhabitants, from 3.7 million in 1992 to 2.8 million in 2017 (Statistics Lithuania, 2017). The great regional differences had first emerged due to the 'central-peripheral' factor, which was the most influential one. Depopulation strikes the strongest in peripheral agricultural regions (Berzins and Zvidrins, 2011; Kriaučiūnas, 2010). In these regions, the birth rate is decreasing, and the share of elderly people is increasing due to young people emigrating to the major cities or abroad. The number of inhabitants in Lithuania has only increased around the major cities, Vilnius, Kaunas and Klaipèda (Ubarevičienè and van Ham, 2017). In peripheral areas (both in towns and villages), the number of inhabitants is decreasing by around two per cent annually, whereas the overall number of inhabitants in these regions has decreased by 30-40 per cent and in some peripheral rural settlements by 50 per cent or more since 1990. The greatest depopulation was observed in small (fewer than 100 inhabitants) settlements (Kriaučiūnas et al., 2014).

\section{Adaptation to the changing socioeconomic environment}

One of the most important factors that influenced the territorial regrouping of the population and the depopulation of peripheral rural areas consists of the changes in the territorial distribution of workplaces. When the previous system collapsed, the territorial settlement system remained the same, but the territorial distribution of workplaces changed. The greatest influence from the loss of jobs in peripheral areas was the collapse of the collective farm (kolkhoz) system.

As mentioned in the methodological section, in this article the adaptation of residents is linked to their adjustment to the labour market. This kind of adaptation has a significant impact on the migration of peripheral inhabitants and influences the changes in their social structure. The main focus is on the population's response to the changing conditions in the socioeconomic environment. Based on our research data, we have developed a theoretical model in which we divided the adaptation of residents to the labour market according to the nature of adaptation (Figure 1). In accordance with this research's objective, we can define three categories of peripheral residents who each in their own way adapted to the socioeconomic changes: those who adapted actively, those who adapted passively and those who did not adapt (Figure 2, Table 1). It is considered that active adaptation involves people of employable age whose income comes from work in public or private service; and who are living and working in the periphery / or other locations 
inside the country / or abroad. Passive adaptation involves pensioners whose income comes mainly from their pension, or children who are dependent on their parents; and who are living in the periphery. Not adapted residents (inadaptability) are those of employable age but who are permanently unemployed and whose income comes from social benefits; and who are living in the periphery.

Tab 1. The adaptation of peripheral residents to the labour market, and the most important problems. Source: authors' own work

\begin{tabular}{|l|l|l|l|l|}
\hline $\begin{array}{l}\text { Group of } \\
\text { residents } \\
\text { according to } \\
\text { age }\end{array}$ & $\begin{array}{l}\text { Adaptation } \\
\text { to the labour } \\
\text { market }\end{array}$ & Income & $\begin{array}{l}\text { Relations to residential } \\
\text { territory }\end{array}$ & Most important problems \\
\hline $\begin{array}{l}\text { Population of } \\
\text { the periphery } \\
\text { of dependent } \\
\text { age: } \text { Children } \\
0-14 \text { years old }\end{array}$ & Passive & $\begin{array}{l}\text { Maintained } \\
\text { by others }\end{array}$ & Potential emigrants & $\begin{array}{l}\text { Most children and young } \\
\text { people do not see any } \\
\text { opportunities in a life in a } \\
\text { peripheral area }\end{array}$ \\
\hline & Active & $\begin{array}{l}\text { Work, } \\
\text { business }\end{array}$ & $\begin{array}{l}\text { Relations depend on the } \\
\text { distance of the workplace } \\
\text { from the settlement }\end{array}$ & $\begin{array}{l}\text { Only about } 50 \% \text { of the rural } \\
\text { population work in the same } \\
\text { settlement they live in. } \\
\text { Greater mobility would } \\
\text { encourage them to work } \\
\text { further away from their place } \\
\text { of residence }\end{array}$ \\
\hline $\begin{array}{l}\text { Population of } \\
\text { the periphery } \\
\text { of working age }\end{array}$ & Inadaptability & $\begin{array}{l}\text { Social } \\
\text { benefits, } \\
\text { accidental } \\
\text { salary }\end{array}$ & $\begin{array}{l}\text { Long-term unemployed, in } \\
\text { particular they have strong } \\
\text { ties to their place of } \\
\text { residence either because } \\
\text { they do not want to move, } \\
\text { or there is no opportunity to } \\
\text { move to another location }\end{array}$ & $\begin{array}{l}\text { The social group which } \\
\text { causes the most social } \\
\text { problems and decreases the } \\
\text { attractiveness of peripheral } \\
\text { areas as a place of } \\
\text { residence }\end{array}$ \\
\hline & Passive & $\begin{array}{l}\text { Pension, } \\
\text { farming }\end{array}$ & $\begin{array}{l}\text { Strong ties to their place of } \\
\text { residence }\end{array}$ & $\begin{array}{l}\text { When more young people } \\
\text { leave peripheral areas, the } \\
\text { number of pensioners } \\
\text { increases. Single pensioners } \\
\text { face the problems of social } \\
\text { vulnerability and an inability } \\
\text { to reach healthcare } \\
\text { institutions }\end{array}$ \\
\hline $\begin{array}{l}\text { Population of } \\
\text { the periphery } \\
\text { of dependent } \\
\text { age: } \\
\text { pensioners } \\
65+\end{array}$ & & & &
\end{tabular}




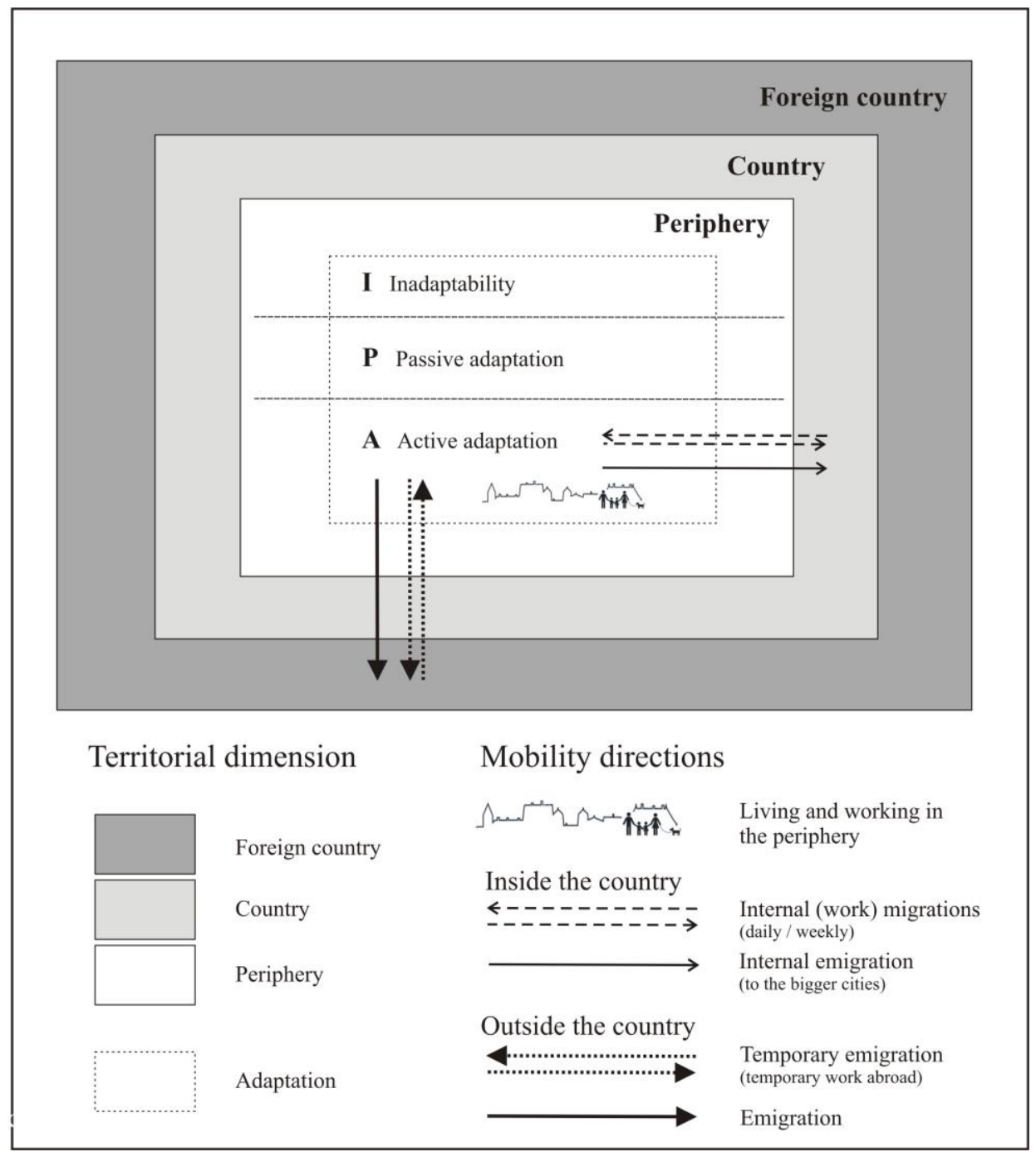

Fig 2. The theoretical model of adaptation of residents of the periphery to the labour market. Source: authors' own work

Work migration is influenced by the residents' chances of finding a job. This migration forms connections between the residents' places of work and residence (Figure 2). The further workplace is from the residence place the weaker links are between residents and residence territory.

It is acknowledged that five possible options for rural development in peripheral areas can be distinguished: intensive agriculture, off-farm employment, rural tourism, nature conservation and multiple development (Berkel and Verburg, 2011: 448). One traditional possibility for adaptation while staying on to live in a rural area is to ensure income from agriculture. Recently (data from 2015), 27 per cent of the rural population in Lithuania were occupied in farming, forestry and fishing. However, we should emphasise that these activities are not the main sources of income for most of those who do farming. Our previous studies (Kriaučiūnas et al., 2014) have shown that rural residents' connections to farming were decreasing. According to the 2011 census data, less than five per cent of the working age population received their main income from agriculture in most of the countryside; and only in some wards did this sector make up more than 20 per cent of the rural population. Only in peripheral areas, in economically more backward regions, the main income of most of the rural population was related to agriculture. Only intensive farming can ensure a sufficient income from agriculture. In order to develop this kind of farming, it is necessary to have (to inherit, lease or buy) huge swathes of agricultural land, which is only successful for a small group of people. After 1990, much of the rural population tried to live off farming. However, this 
income could not guarantee a living for most independent farmers, so income from farming was only something extra (e.g., various EU subsidies for meadows etc.). When the farms became bigger, the main farmers (managing and leasing several hundred ha) received most of the income and EU financial support.

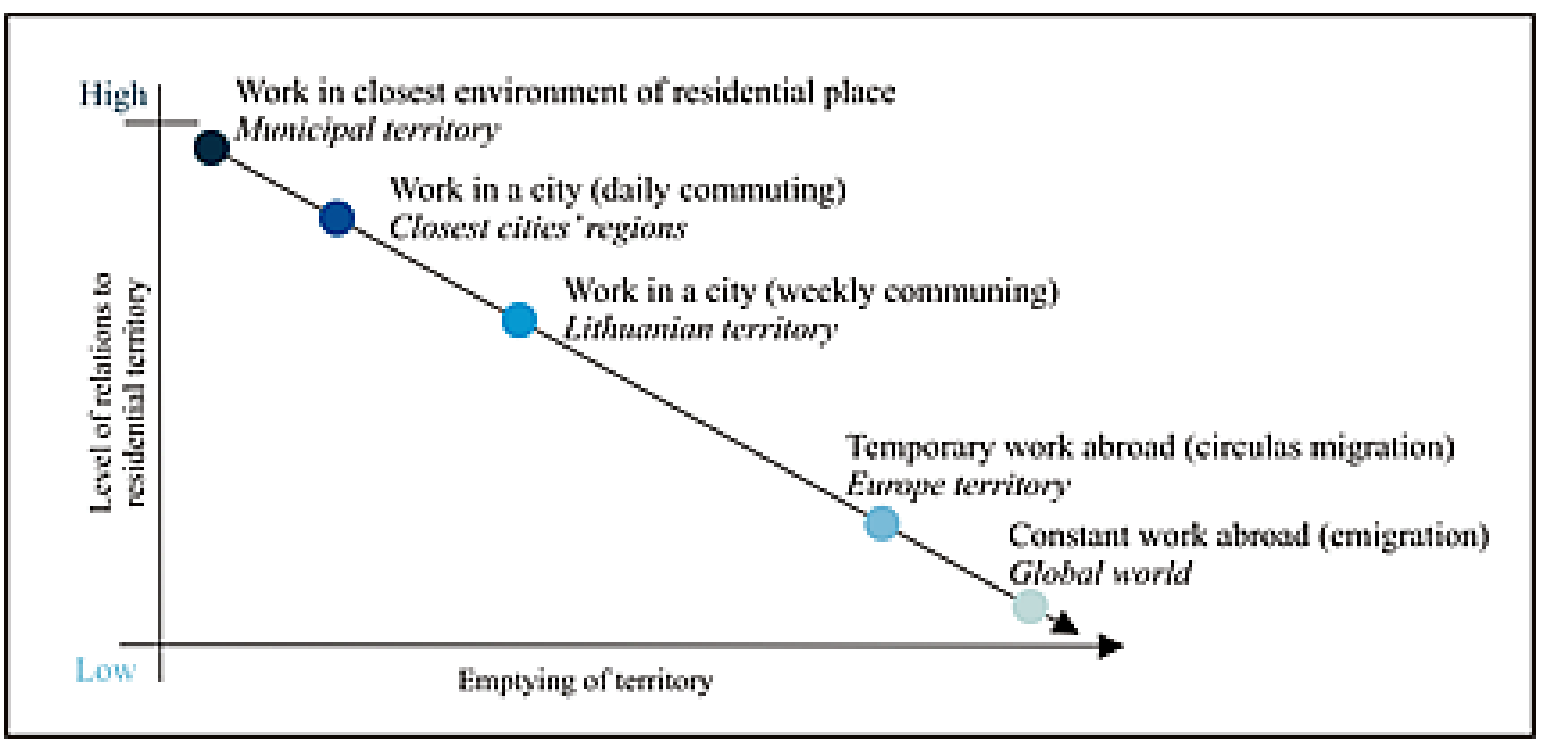

Fig 3. Relations of employable population of the periphery to the residential area depending on the workplace. Source: authors' own work

Without agriculture, there were / are other activities where the work place can guarantee an income for the population: forestry, small industrial companies, services for holidaymakers in the countryside and so on. However, in these areas there were and still are fewer jobs than working-age residents. One possible way of using peripheral rural areas is to increase recreational and tourist services. Just two-three per cent of the entire working-age rural population work in the accommodation and catering industries. Therefore, in rural territories, the accommodation business does not play a significant role, although there are some regions where this business is in fact significant. In some areas that are intensively used for recreation during the high season, up to 50 per cent of jobs there are in the accommodation business. However, there are only a few of these areas, according to our calculations around 20 wards (out of a total of 471 rural wards).

A great part of residents work in the private sector, whereas in the public sector $(24.1$ per cent of employed rural population) the residents mainly work in the sphere of education (8.2 per cent of employed rural population); also in public administration structures (5.1 per cent of employed rural population); and in healthcare (5.3 per cent of employed rural population).

The traditional activities in rural areas can only provide jobs for a small part of the rural population that makes this one of the factors encouraging depopulation. Due to this tendency of decreasing numbers of jobs that ensure at least a minimal income, most rural residents have to leave their places of residence every day (or every week, returning home at weekends) to go to work in other areas (in big cities or abroad) (Figure 3). According to the 2011 census data, around half of the rural population in Lithuania do not work in the same place they live (Kriaučiūnas et al., 2014). 


\section{The influence of social and demographic changes on socio-spatial inequalities}

Firstly, the depopulation of peripheral areas was and still is influenced by the emigration of young people either abroad or to major cities in Lithuania (Pocius, 2007; Vaitekūnas, 2006). Young people simply do not see any opportunities in peripheral areas and try to leave ('escape'):

'Youngsters are leaving. Even the kids of rich farmers do not want to return to their villages after their studies', (Ward chairman, Šiaulènai village, Radviliškis district).

'It's a rather sad image of the village. Only old people remain, the youngsters leave and do not come back. There is simply nothing here to attract them', (Ward chairman, Tverai village, Rietavas district).

'After the Soviet Union collapsed, a lot of young specialists left the villages. Currently, youngsters are also leaving and not coming back. But this is normal - the number of residents in the villages should be decreasing as there is nothing to do here, no work opportunities', (Ward chairman, Žilinai village, Varèna district).

Interviews with local authorities allowed us to identify two main groups of young people when we talked about emigration from peripheral areas: a) those who leave to study, and b) those who leave to work. Those who leave to study in high schools do not return to the peripheral areas in most cases (as well as in the Soviet era) (Pocius, 2007; Ubarevičienè and van Ham, 2017). The work circumstances of the young people who leave to work in other areas are different: some emigrate out of the countryside, some work abroad periodically, and some work in other parts of Lithuania and return home at weekends.

During this research, we found out that not only was the abandonment of peripheral areas occurring, but also population segregation; the regions that were losing their population the fastest were also experiencing fundamental changes in their social structure. Young people (up to 35 years old) are the most mobile and inclined to leave (Ubarevičiene and van Ham, 2017). Immigration to peripheral regions is very low and the immigrating people are elderly and less-educated. These people whose income consists of a pension or social benefits stay on to live in the countryside. Due to the depopulation process, sparsely inhabited areas where the population density does not reach ten, or in some cases five residents, per square kilometre, are increasing in peripheral regions (Daugirdas et al., 2013; Kriaučiūnas and Daugirdas, 2013).

Therefore, the shrinkage process is partly the result of economic changes, although it also leads to problems (challenges) itself of specific socio-economic, demographic, etc. In peripheral rural areas, in the last 25 years, the social-territorial model's influence on the new economic relations has become clear. Despite peripheral regions being poorer compared to cities, within them - at the local level - social segregation, which can be seen very clearly in locations with smaller populations, has also become apparent. A 'mini model' has emerged - against a general background of people who live poorly and receive social benefits or pensions, there are single homesteads belonging to rich farmers. Rich farmers also often invest in other businesses - they buy local shops, build rural tourist homesteads, buy forests. As a result of all these changes social differences are only increasing.

\section{Unemployment, social benefits and alcohol}

The changing demographic and social structure of society influences a number of problems in peripheral areas. The interviews disclosed that the problems of families/persons at social risk are topical in these areas. The respondents explained the formation of this social class differently: some chairs of wards indicated unemployment (which led to alcoholism) as the main reason, whereas others stressed alcoholism (which led to an unwillingness to work) as the number one reason. The absolute majority of respondents emphasised that social policy (regulations for social benefits) implemented by the government was very 'helpful' for the creation of a 'social benefitreceiving class': 
'Social benefits spoil people. I think there shouldn't be any benefits at all', (Ward chairman, Liaušiai village, Ukmergè district).

'Benefits spoil the residents because they do not want to work. Farmers cannot find workers because nobody wants to work a full day. Some families receive social benefits that are worth more than the salary of a ward employee', (Ward chairman, Šaukotas village, Radviliškis district).

'Alcohol is a big problem. We have single people and even entire families who drink heavily. And this alcoholism began in Soviet times', (Ward chairman, Kriaunos village, Rokiškis district).

The issue of caring for social-risk families and the reduction of risk is topical and especially hard to solve in Lithuania (Kondrotaite 2006). During our research, there was not one case when the representatives of the rural community complained about state social politics and the actual means applied by the local authorities. Sometimes social housing is found for residents who ask for it and who live in almost deserted rural places with the hope of not only providing them with accommodation, but also 'rescuing' almost empty schools because families at social risk are usually quite big. However, these newcomers integrate with difficulty, and the children, as soon as they become adults, register as unemployed and choose the familiar lifestyle of their parents. It is very difficult to escape from this 'cycle', and ongoing changes in the social structure decrease the attractiveness of peripheral areas as a place of residence place even further. The representatives shared with us the following experience:

'Social benefits are defective. They create a 'closed cycle', as when people receive social benefits they lose their willingness to work', (Ward chairman, Tauragnai village, Utena district).

'A big family receiving benefits came to our village to live in social housing. We were happy and waiting for them as we thought that it would increase the number of pupils at the local school... But when these kids grew up, they went straight to register at the labour exchange to receive social benefits. And what else did they know? That's what they learned from their parents...', (Community chairman, Daukšiai village, Skuodas district).

'I wanted to hire a cleaner for half a day to tidy up the ward. The salary for the cleaner was the same as social benefits, so what is the point of him/her working?', (Ward chairman, Antalieplè village, Zarasai district).

The number of social-risk families and the image of settlements sometimes occur as a Soviet 'heritage'. It is especially relevant for settlements that used to be industrial. One example is Tyruliai settlement (Radviliškis district), which was an important peat exploitation centre during the Soviet period. In this (and other similar settlements), rural settlement blocks of flats were built that became particularly unpopular after the 1990s when people belonging to the social-risk group started to settle there. The chairman of Tyruliai village explained to us that:

'We have around 20-30 inhabitants (out of around 200) that are serious alcoholics. When the apartments started to become empty in 1991-1992, shrewd 'businessmen' from the nearest major city Šiauliai forced drunk people out of their homes in Šiauliai and moved to Tyruliai. These newcomers create a negative image of the settlement'.

Other settlements that were also significantly expanded during the Soviet period face similar problems:

'Our settlement is artificial. The settlement expanded in 1982 when a huge pig farm was built. Until that time, the majority of the residents worked in forestry. The pig farm was built by prisoners who stayed on to live in our settlement after they finished their work. After the 1990s, they did not want to work. Several generations of beneficiaries have already 
grown up. They even dared to send their little kids to me to ask when their social benefits will be paid', (Ward chairman, Lekèčiai village, Šakiai district).

\section{The positive side of living in a rural territory}

Despite the changes that have happened in Lithuanian, peripheral areas and which have negative connotations in people's minds, it is possible to find positive changes that are not only objectively measured (e.g., the growth of agricultural productivity etc.), but that are also felt and presented by the local residents in peripheral areas:

'Little by little, things are getting better. After the Independence period our community stabilised - those who didn't want to live in the village left. Those who stayed want to live here and keep busy', (Ward representative, Kraštai village, Pasvalys district).

'Our residents are happy to live in this settlement because there is tourism here. With regard to work opportunities: everyone who wants a job finds one', (Ward chairman, Veliuona village, Jurbarkas district).

'Our settlement is calm. The residents are sociable. Young families are settling here. We have a cultural centre, a choir, two groups of dancers. A lot of people come to our events. We are sure that the settlement will have a bright future', (Ward chairman, Žlibinai village, Plungè district).

Our community is active. We have a number of artistic collectives. We have young people who stay on to live in the village. We think our future is bright. (Ward specialist, Taujenai village, Ukmergè district).

Here, we have indicated several examples that allow us to conclude that an optimistic picture of the future is presented in those settlements that have a greater sense of community. The future of the village is linked to the communal activities (see also Chevalier et al., 2017; Juska et al., 2005), and undoubtedly to young people as well.

A fact that was identified during the earlier research should also be mentioned (Daugirdas et al., 2013): enquiries undertaken in sparsely populated areas $^{4}$ (602 residents answered the interviewer) showed that an absolute majority of respondents enjoyed their lives in their settlement (66.7 per cent - enjoyed, 26.5 per cent enjoyed very much). A quiet environment, a good ecological situation, and being born and raised in that ward were the main reasons residents in sparsely populated territories gave about why they liked their settlements and lived there. The fact that jobs are becoming more mobile and people can work online without physically being in their specific place of work (e.g., in the city) also plays a big role in attracting people to live in peripheral areas. This might be particularly applicable to the warm period of the year. There are already a number of homesteads where city residents come to live during the summer. Precisely, these 'summer resettlements' could become a development opportunity in peripheral areas.

\section{Discussion and conclusions}

Some tendencies and problems of social development in peripheral areas in Lithuania have been raised and discussed in this article. The topic of economy was not touched on in this article, although the general economic tendencies in Lithuania have improved (European Commission, 2017), labour productivity has increased, agricultural production has been more than in the Soviet era, although almost three times fewer people work in agriculture. However, the improvement in overall economic welfare is poorly reflected in the lives of people from peripheral areas. Interviews that were conducted with local authorities and the results of previous studies by other scholars

\footnotetext{
4 A sparsely populated area (SPA) is defined as a territory where the rural population density does not exceed $12.5 \mathrm{inh} . / \mathrm{km}^{2}$. The project identified 183 wards that might be called SPAs. These areas take up 45 per cent of Lithuanian territory.
} 
(Daugirdas et al., 2013; Kondrotaitè, 2006) confirm the statement that part of rural people constantly faces poverty and other fundamental problems.

Scientists, economists, architects and politicians are divided into two groups when they look for a strategy for the development of Lithuania. However, scientific discussion and the appearance of this topic in articles are rare; more often discussions appear in the media, both on television and in publications, or during political debates. One group thinks and claims that the settlement system created during the Soviet era no longer meets modern neoliberal conditions, and that the populations of peripheral areas necessarily have to decrease and villages disappear, and that any attempt to maintain their vitality is a pointless waste of money (Burneika, 2006, 2012; Juškevičius, 2015; Ubarevičienè and van Ham, 2017). Another group says that it is necessary to maintain the vitality of settlements, it is not a matter of whether they are a capital or small town in a peripheral area; the country must invest in the infrastructure of rural places, and encourage the creation of jobs with financial measures (Dringelis, 2013; Juska et al., 2005; Kavoliutè, 2014). Due to the subtleties of the electoral system, politicians usually support the second group. Against this background of disputes, both groups partially win: in recent years, a lot of EU finances have been invested to refurbish buildings, roads, and water-supply and sewage systems, although to the 'joy' of the neoliberal supporters, the development programs for peripheral areas are disappearing. Out of all these 'winners', there is only one 'loser', the people living in peripheral areas, because in the fight over various people's interests (essentially due to money), they are simply left aside.

In our opinion, it is not the territory that is most important, but the actual person who lives there. It is necessary to acknowledge that if in the former Soviet Union new economic relations were taken over and adapted fairly quickly, then other valuable attitudes changed very slowly, one of which is the attitude towards people. Usually, the territory itself but not the person living in it becomes the centre of attention and in our opinion this is the basic problem of peripheral studies.

Taking everything into account and following the definition of periphery presented by Blowers and Leroy (1994), Copus (2001), Elcock (2014), Kühn (2015), Willett (2010) and other scholars, it might be stated that peripheral rural areas in Lithuania are not only physically but also demographically and socially distant and different from urban territories while looking at the structure of residents. The interviews with local authorities revealed that the peripheries are politically powerless to take their own decisions or development strategies. The work plan of local authorities and the life of rural residents are dependent on central authority and their decisions. Usually, the look to the periphery goes from the city perspective while stigmatizing rural settlements as lagging behind territories, and such negative viewpoint becomes one of the reasons' for younger people to emigrate to the cities or abroad.

It is obvious that the neoliberal environment has been very favourable for the growth of the polarisation of territory in modern Lithuania. Looking around more widely, the central-peripheral factor is universal and more related to the territorial organisation of society and the development of the overall economy than the political system. Only the extent of peripheralisation differs and, in our opinion, it is not the peripheralisation itself that is the problem, but its speed caused by the new economic order. 


\section{Academic references}

[1] Berzins, A. \& Zvidrins, P. (2011). Depopulation in the Baltic states. Lithuanian Journal of Statistics 50(1), 39-48.

[2] Blowers, A. \& Leroy, P. (1994). Power, politics and environmental inequality: A theoretical and empirical analysis of the process of "peripheralisation". Environmental Politics 3, 197-228. DOI: $10.1080 / 09644019408414139$.

[3] Burbulytè-Tsiskarishvili, G. (2012). Measuring Peripherality and Accessibility for Lithuanian Regional Policy. Regional Formation and Development Studies 8(3), 25-35.

[4] Bürk, T. (2013). Voices from the Margin: The Stigmatization Process as an Effect of SocioSpatial Peripheralization in Small-Town Germany. In Fischer-Tahir, A. \& Naumann, M., eds., Peripheralization. The Making of Spatial Dependencies and Social Injustice (pp. 168-185). Wiesbaden: Springer VS.

[5] Burneika, D. (2006). Peculiarities of economic relations between former Soviet countries influence of different heritage. Geopolitical Studies 14, 409-420.

[6] Burneika, D. (2012). Transformations in Lithuania - factors of change and regional patterns. In Gorzelak, G., Goh, C. C. \& Fazekas, K., eds., Adaptability and Change: The Regional Dimensions in Central and Eastern Europe (pp. 267-283). Drelow: Poligraf.

[7] Chevalier, P., Mačiulyté, L., Razafimaheva, L. \& Dedeire, M. (2017). The Leader Programme as a Model of Institutional Transfer: Learning From its Local Implementation in France and Lithuania. European Countryside 9(2), 317-341. DOI: 10.1515/euco-2017-0020.

[8] Copus, A. K. (2001). From Core-periphery to Polycentric Development: Concepts of Spatial and Aspatial Peripherality. European Planning Studies 9(4), 539-552. DOI: $10.1080 / 713666491$.

[9] Daugirdas, V., Burneika, D., Kriaučiūnas, E., Ribokas, G., Stanaitis, S. \& Uberevičiuné, R. (2013). Lietuvos retai apgyventos teritorijos. Vilnius: Lietuvos socialinių tyrimų centras.

[10] Daugirdas, V. \& Burneika, D. (2008). Peripherality and peripheral regions in Lithuania borderland of EU. In Baubinas, R., ed., Problem regions in Lithuania (sociogeographical aspect) (pp. 6-12). Vilnius: Geografijos ir geologijos institutas.

[11] Deleuze, G. (2004). Desert islands and other texts. Cambridge, MA and London: MIT Press.

[12] Dringelis, L. (2013). Lietuvos miestai, miesteliai ir kaimai: ju urbanistinių ir demografinių pokyčių įtaka šalies kraštovaizdžio erdvinès struktūros savitumui Juornal of architecture and urbanism 37(4), 310-323. DOI: 10.3846/20297955.2013.869884.

[13] Elcock, H. (2014). Multi-level governance and peripheral places: The North-East of England. Local Economy 29(4-5), 323-333. DOI: 10.1177/0269094214541524.

[14] Eriksson, M. (2008). (Re)Producing a "peripheral" region - Northern Sweden in the news. Geografiska Annaler: Series B, Human Geography 90, 369-388. DOI: 10.1111/j.14680467.2008.00299.x.

[15] Gutiérrez, J. \& Urbano, P. (1996). Accessibility in the European Union: the impact of the Trans European road network. Journal of Transport Geography 4(1), 15-25. DOI: 10.1068/a301337.

[16] Janc, K. (2006). Human and social capital in Poland - spatial diversity and relations. Europa $X X I 14,39-55$.

[17] Jeřábek, M. (2006). Research into peripheral areas in the Czech Republic - changes in the landscape and land use in the model regions. Europa XXI 15, 171-183. 
[18] Juska, A., Poviliunas A. \& Pozzuto, R. (2005). Resisting Marginalisation: The Rise of the Rural Community Movement in Lithuania. Sociologia Ruralis 45(1-2), 3-21. DOI: 10.1111/j.14679523.2005.00287.x.

[19] Juškevičius, P. (2015). Lietuvos miestų sistemos raida ir jos ateities perspektyvos. Acta Academiae Artium Vilensis 76, 11-34.

[20] Kavoliutè, F. (2014). Gyvenamujų vietovių vardai - nematerialusis šalies kultūros paveldas [Place names - intangible cultural heritage]. Geografijos metraštis 47, 88-102.

[21] Keeble, D. E. (1989). Core-periphery disparities, recession and new regional dynamisms in the European Community. Geography 74(1), 1-11.

[22] Kinsey, B. S. (2006). Cleavage formation in Norway: The Contextual Dimension. Scandinavian Political Studies 29(3), 261-283. DOI: 10.1111/j.1467-9477.2006.00152.x.

[23] Kondrotaitè, G. (2006). Socialinès rizikos šeimos Lietuvoje: atvejo studija. Filosofija.Sociologija 4, 55-60.

[24] Kriaučiūnas, E., Krupickaité, D., Pociūté-Sereikiné, G. \& Ubarevičiuné, R. (2014). Lietuvos kaimo gyvenviečių funkcijų kaitos regioninès ypatybès. Geografijos metraštis 47, 70-87.

[25] Kriaučiūnas, E. (2010). Some development patterns of Lithuanian rural territories in 19902010. Geopolitical Studies 16, 199-212.

[26] Kriaučiūnas, E. \& Daugirdas, V. (2013). Rečiausiai gyvenamų Lietuvos teritorijų gyvenviečių tinklo ypatumai Geografijos metraštis 46, 32-45.

[27] Krugman, P. R. (2010). The New Economic Geography, Now Middle-aged. Regional Studies 45(1), 1-7. DOI: 10.1080/00343404.2011.537127.

[28] Kühn, M. (2015). Peripheralization: Theoretical Concepts Explaining Socio-Spatial Inequalities. European Planning Studies 23(2), 367-378. DOI: 10.1080/09654313.2013.862518.

[29] Kühn, M. \& Bernt, M. (2013). Peripheralization and power - Theoretical debates. In FischerTahir, A. \& Naumann, M., eds., Peripheralization - The making of spatial dependencies and social injustice (pp. 302-317). Wiesbaden: Springer VS.

[30] Lang, T. (2012). Shrinkage, Metropolisation and Peripheralisation in East Germany. European Planning Studies 20(10), 1747-1754. DOI: 10.1080/09654313.2012.713336.

[31] Lang, T. (2015). Socio-economic and political responses to regional polarisation and sociospatial peripheralisation in Central and Eastern Europe: a research agenda. Hungarian Geographical Bulletin 64(3), 171-185. DOI: 10.15201/hungeobull.64.3.2.

[32] Mačiulytè, J. \& Bagočiūtè, A. (2008). Regional Developement Disparities and Regional Policy in Lithuania after Accession to the European Union. In Gaidoš, P., ed., Regional Disparities in Central Europe (pp. 87-97). Bratislava: Interlingua.

[33] Maldžiūnas, V. (1970). Teritorinių mikrorajony centru tinklas Lietuvos TSR [PhD thesis]. Kaunas: Kauno politechnikos institutas.

[34] Marada, M., Chromý, P., Jančák, V. \& Havlíček, T. (2006). Space polarization and peripheral regions in Czechia. Europa XXI 15, 29-34.

[35] Miggelbrink, J. \& Meyer, F. (2015). Lost in Complexity? Researching the Role of Socio-Spatial Ascriptions in the Process of Peripheralization. In Lang, T., Henn, S., Ehrlich., K. \& Sgibnev, W., eds., Understanding Geographies of Polarization and Peripheralization (pp. 62-79). Basingstoke: Palgrave.

[36] Nagy, G. (2006). Economic potential of regions - modelling the spatial structure of Hungary in the period of transition. Europa XXI 14, 7-26. 
[37] Pocius, A. (2007). Changes in internal territorial Lithuanian resident mobility and influence of migration of labour market. Survey of Lithuanian economy 2, 24-32.

[38] Pociūtè, G. (2014). Trends of imbalances of demographic and socioeconomic development in post-reform period in Lithuania. In Churski, P., ed., The social and economic growth vs. the emergence of economic growth and stagnation areas (pp. 129-150). Poznan: Bogucki Wydawnictwo Naukowe.

[39] Pociūtè-Sereikienè, G., Kriaučiūnas, E. \& Ubarevičienè, R. (2014). Peripheralisation trends in rural territories: the case of Lithuania. Studies in Agricultural Economics 116, 122-130. DOI: $10.7896 / \mathrm{j} .1421$.

[40] Rokkan, S. \& Urwin, D. W. (1982). Introduction: Centres and peripheries in Western Europe. In Rokkan, S. \& Urwin, D. W., ed., The Politics of territorial identity: Studies in European regionalism (pp. 1-17). London: SAGE Publications.

[41] Rupas, V. \& Vaitekūnas, S. (1980). Lietuvos kaimo gyventojai ir gyvenvietės [Lithuanian rural population and settlements]. Vilnius: Mintis.

[42] Šešelgis, K. (1975). Rajoninio planavimo ir urbanistikos pagrindai. Vilnius: Mintis.

[43] Šešelgis, K. (1996). Teritoriju planavimo raida Lietuvoje. Urbanistika ir Architektūra 21(1), 419.

[44] Spiekermann, K. \& Wegener, M. (1996). Trans-European Networks and Unequal Accessibility in Europe. European Journal of Regional Development 4, 35-42.

[45] Spoor, M. (2013). Multidimensional Social Exclusion and the 'Rural-Urban Divide' in Eastern Europe and Central Asia. Sociologia Ruralis 53(2), 139-157. DOI: 10.1111/soru.12008.

[46] Swain, N. (2016). Eastern European Rurality in Neo-Liberal, European Union World. Sociologia Ruralis 56 (4), 574-596. DOI: 10.1111/soru.12131.

[47] Ubarevičienè, R. \& van Ham, M. (2017). Population decline in Lithuania: who lives in declining regions and who leaves? Regional Studies, Regional Science, 4(1), 57-79. 10.1080/21681376.2017.131312.

[48] Vaishar, A. (2006). Regional periphery: What does it mean? Europa XXI 15, 7-12.

[49] Vaitekūnas, S. (1989). Gyvenviečiu geografija. Vilnius: Vilniaus Universitetas.

[50] Vaitekūnas, S. (2006). Lietuvos gyventojai: Per du tūkstantmečius. Vilnius: Mokslo ir enciklopedijų leidybos institutas.

[51] Van Berkel, D. B. \& Verburg, P. H. (2011). Sensitising rural policy: Assessing spatial variation in rural development options for Europe. Land Use Policy 28(3), 447-459. DOI: 10.1016/j.landusepol.2010.09.002.

[52] Vanagas, J., Kriśjane, Z., Noorkoiv, R. \& Staniunas, E. (2002). Planning urban systems in Soviet times and in the era of transition: the case of Estonia, Latvia and Lithuania. Geographia Polonica 75(2), 75-100.

[53] Willett, J. (2010). Why is Cornwall So Poor? Narrative, Perception and Identity [PhD thesis]. Exeter: University of Exeter. 
[54] Census 1989 (1991). Lithuanian 1989 population census data. Vilnius: Statistics Lithuania.

[55] European Commission (2017). Commission Staff Working Document. Country Report Lithuania 2017. SWD (2017) 80 final. Available online at: https://ec.europa.eu/info/publications/2017-european-semester-country-reports_en Accessed 22 February 2017.

[56] LR Vyriausybès nutarimas (2003). Dél probleminiu teritoriju išskyrimo kriteriju [LR Government decision "Due to the criterion to distinguish problem territories"]. Act. No. 35-1483.

[57] LR Vyriausybès nutarimas (2007). Dél probleminiu teritoriju [LR Government decision "Due to problem territories"]. Act. No. 15-555.

[58] Lyman, R. (2016). Like Trump, Europe's Populist Win Big With Rural Voters. The New York Times December

6. Available online https://www.nytimes.com/2016/12/06/world/europe/europe-poland-populism-ruralvoters.html?_r=2 Accessed 7 December 2016.

[59] Raagmaa, G. (2003). Centre-periphery model explaning the regional development of informational and transitional society. Conference abstract. $43^{\text {rd }}$ Congress of the European regional science association (ERSA) in Jyväskylä, Finland, 27-30 August 2003. Available online at: http://www.jyu.fi/ersa2003/cdrom/abstracts/a503.html Accessed 15 January 2017.

[60] Statistics Lithuania (2017). Database of indicators. Available online at: http://osp.stat.gov.lt/en/statistiniu-rodikliu-analize1 ?epoch=ML Accessed 12 December 2016. 